4 el Hassani S, Echarrab el-M, Bensabbah R, Attaibi A, Kabiri H, Bourki K, et al. Primary psoas abscess. A review of 16 cases. Rev Rhum Engl Ed 1998;65:555-9.

5 Williams MP. Non-tuberculous psoas abscess. Clin Radiol 1986;37:253-6.

6 Isabel L, MacTaggart P, Graham A, Low B Pyogenic psoas abscess. Aust N Z J Surg 1991; 61:857-60.

7 Santaella RO, Fishman EK, Lipsett PA. Primary vs secondary iliopsoas abscess. Arch Surg 1995; 130:1309-13.

8 Chern CH, Hu SC, Kao WF, Tsai J, Yen D, Lee $\mathrm{CH}$. Psoas abscess: making an early diagnosis in the ED. Am J Emerg Med 1997;15:83-8.

9 Kao PF, Tzen KY, Tsui KH, Tsai MF, Yen TC. The specific gallium-67 scan uptake pattern in psoas abscesses. Eur J Nucl Med 1998;25: psoas a

10 McAuliffe W, Clarke G. The diagnosis and treatment of psoas abscess: a 12 year review. Aust N Z J Surg 1994;64:413-17.

\section{Klippel-Feil syndrome in the prehispanic population of E1 Hierro (Canary Islands)}

Klippel-Feil syndrome is an uncommon alteration (1:40 000 births), mainly affecting the cervical spine. ${ }^{1}$ The classic clinical triad described by Klippel and Feil in 1912 - short neck, low dorsal hairline, and restricted neck mobility - is the result of the fusion of a variable number of cervical vertebrae, sometimes reducing their number, and cervical spina bifida. ${ }^{2}$ Extraosseus changes, ${ }^{3}$ hemivertebra, vertebral body clefts, and thoracolumbar abnormalities, ${ }^{4}$ are sometimes seen

In a prehispanic ossuary containing remains of at least 121 subjects in the island of El Hierro (Canary Islands), we noted:

1 A C2-3 block, with the two vertebrae fused both by the vertebral bodies and the medial ends of the archs, well preserved right intervertebral foramina, and foramina transversaria (fig 1), and a normal medullar canal. The body of the third vertebra shows intense degenerative signs.

2 A C5-6 block, consisting of two vertebrae with intense degenerative changes fused both by the vertebral bodies and the medial part of the archs. Both cervical blocks seem to belong to the same subject.

3 A well preserved atlas bone, with an incomplete anterior part of the left arch,

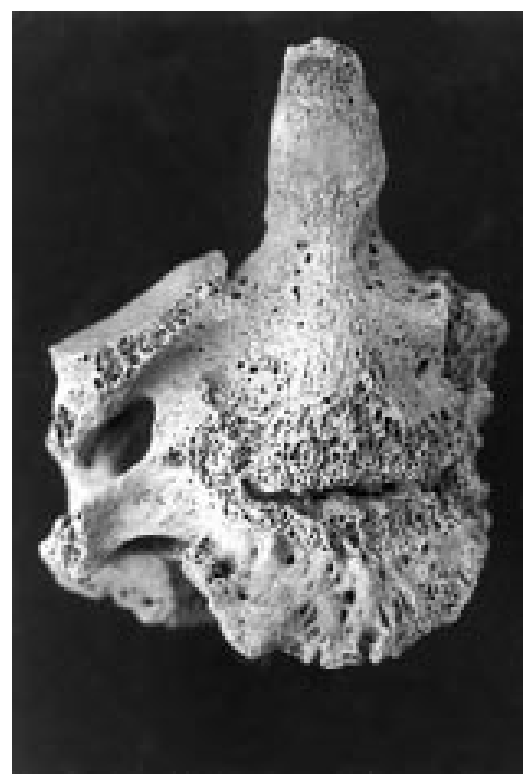

Figure 1 Fused C2-3 vertebral block.
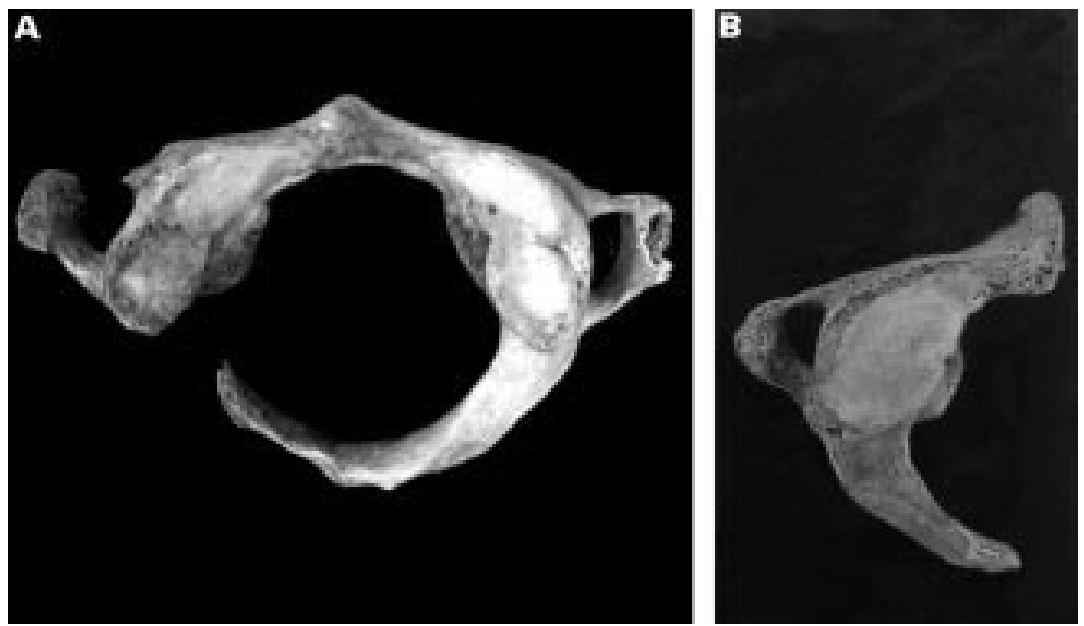

Figure 2 (A) Atlas with a hypoplastic left arch; the lack of fusion of the anterior arch of the left foramen transversarium is also evident. (B) Left hemiatlas.

with sharp, fine proximal, and distal ends (fig 2A), supporting an underlying developmental defect rather than an acquired one.

4 A left hemiatlas (fig 2B); although it is possible that the right body of the bone was partially fused with the left one (and was not recovered in the archaeological excavation), the posterior end of the arch was neither fractured nor fused to any other bony structure, thus pointing to a developmental defect.

Fusion of C2 and C3 (and C5-6), hypoplasia of the arch of the atlas, ${ }^{5}$ and complete bipartition of the atlas ${ }^{6}$ constitute distinctive features of Klippel-Feil disease. Thus the subject with the fused C2-3 and C5-6 blocks and the hemiatlas was probably affected by this disease. Possibly, the second atlas belongs to another subject with the same disease, though this possibility should be cautiously admitted. The two atlas bones show different developmental abnormalities. In the newborn, the ossification of the cartilaginous anterior and posterior archs of the atlas takes place progressively from the already ossified lateral masses. Often, especially in the anterior arch, secondary ossification centre(s) appear. ${ }^{7}$ In our case it seems that hypoplastic development of the anterior left arch took place. Because the hypoplastic part of the arch is in its middle part, probably, a second ossification centre was present, but ossification was never completed; in this sense, it is similar to the case described by Chigira et $a l,{ }^{5}$ which also showed fusion of C5-6.

The "hemiatlas" perhaps is really an atlas with a midline cleft and a lost half, though the posterior arch does not reach the midline, so it never became fused with the right half of the bone. A secondary posterior ossification centre sometimes appears during the first years of life. In this case, it was absent, in contrast with the anterior secondary ossification centre which was surely present in the former case.

Perhaps familial links existed between the two subjects. Klippel- Feil syndrome is a heterogeneous disorder, showing different alterations in different families. ${ }^{8}$ The simultaneous finding of different developmental abnormalities of the atlas in our two casesassuming that the second one truly represents a case of Klippel-Feil-may either reflect an unusually high prevalence of this entity in the prehispanic population of El Hierro, or may also indicate that even in the same family clinical expression of the Klippel-Feil syndrome is variable.

E GONZÁLEZ-REIMERS A MAS-PASCUAL Dpto de Medicina Interna, Hospital Universitario de Canarias,

Tenerife, Canary Islands

M ARNAY-DE-LA-ROSA J VELASCO-VÁZQUEZ

M C JIMÉNEZ-GÓMEZ

Dpto de Prehistoria, Antropología e Historia Antigua,

Universidad de la Laguna,

Tenerife, Canary Islands

Correspondence to: Dr González-Reimer

1 Thomsen MN, Schneider U, Weber M, Johain nisson R, Niethard FU. Scoliosis and congental anomalies associated with Klippel-Feil syndrome types I-III. Spine 1997;22:396-401.

2 Chaumien JP, Rigault P, Maroteaux P, Padovan JP, Touzet T. Le soi-disant syndrome de Klippel-Feil et ses incidences orthopediques. Rev Chir Orthop 1990;76:30-8.

3 Hensinger RN, Lang JE, McEwen GD. Klippe Feil syndrome. J Bone Joint Surg Am 1974;56: 1246-53.

4 David KM, Copp AJ, Stevens JM, Hayward RD, Crockard HA. Split cervical spinal cord with Klippel-Feil syndrome: seven cases. Brain Klippel-Feil syndron

5 Chigira M, Kaneko K, Mashio K, Watanabe $\mathrm{H}$ Congenital hypoplasia of the arch of the atlas with abnormal segmentation of the cervical spine. Arch Orthop Trauma Surg 1994;113: $110-12$.

6 Wolf RF, Klein JP. Complete bipartition of the atlas in the Klippel-Feil syndrome. A radiologically illustrated case report. Surg Radiol Anat 1997;19:339-40.

Williams PL, Warwick R, eds. Gray's anatomy. Philadelphia: Saunders, 1980

8 Clarke RA, Catalan G, Diwan AD, Kearsley JH. Heterogeneity in Klippel-Feil syndrome: a new classification. Pediatr Radiol 1998;28:967-74.

\section{Haematopoietic stem cell} transplantation (HSCT) in a patient with Sjögren's syndrome and lung malt lymphoma cured lymphoma not the autoimmune disease

Haematopoietic stem cell transplantation (HSCT) has been used in an attempt to control autoimmune diseases that respond poorly to conventional treatment, or as a way 
of readjusting the immunological balance. ${ }^{1}$ As far as we know, only one case of primary Sjögren's (SS) has been reported, ${ }^{2}$ with an unfavourable outcome. Another patient received an allogeneic bone marrow transplant and also had an unfavourable outcome. ${ }^{3} \mathrm{We}$ describe here a further patient with primary SS who underwent HSCT for a nonHodgkin's lymphoma affecting the lung (large cell, mucosa associated lymphoid tissue (MALT) lymphoma) and review the literature on the effects of HSCT on the autoimmune features and histopathological changes in primary SS.

\section{Case report}

A white woman, aged 42 , developed recurrent parotid swelling and symptomatic sicca syndrome, with a Schirmer's test I of $5 \mathrm{~mm}$ in the right eye and $4 \mathrm{~mm}$ in the left eye. Break up time was $6 \mathrm{~s}$ and sialometry was $<1 \mathrm{ml}$.

She had periodic relapses of her parotid swelling. In August 1994 (aged 57) lung $x$ rays and computed tomography disclosed a parenchymal nodule of $3 \mathrm{~cm}$ in diameter in the basal left lobe. She underwent a lobectomy that disclosed a MALT, of the large cell B lymphoma histotype, stage IE. In December 1994 two more nodules in the right lobe, with hilar bilateral adenomegaly, led to the diagnosis of a relapse of her lymphoma, which had progressed to stage IV. She then received six courses of F-MACHOP (vincristine $0.5 \mathrm{mg} / \mathrm{m}^{2}$ at hours 0 and 12 ; cyclophosphamide $800 \mathrm{mg} / \mathrm{m}^{2}$ intravenous (IV) bolus at hour 36, 5-fluorouracil $15 \mathrm{mg} / \mathrm{kg}$ IV for six hours at hour 36, cytosine-arabinoside 1000 $\mathrm{mg} / \mathrm{m}^{2}$ IV for six hours at hour 42 , doxorubicin $60 \mathrm{mg} / \mathrm{m}^{2}$ IV bolus at hour 48 , methotrexate $500 \mathrm{mg} / \mathrm{m}^{2} \mathrm{IV}$ for six hours at hour 60 , prednisone $60 \mathrm{mg} / \mathrm{m}^{2}$ from day 1 to $14)$, and folinic rescue $\left(20 \mathrm{mg} / \mathrm{m}^{2}\right.$, IV bolus at hours $84,96,108,120)$, with a prompt reduction of hilar adenopathies and a net decrease of pulmonary nodule size. However, no complete remission was recorded. She was then offered the possible chance of an HSCT. Table 1 (patient 1) reports the myeloablation, conditioning, recovery, and reinfusion of stem cells. After three years of follow up no relapse of the lymphoma has occurred. Sicca syndrome after transplantation was unmodified, however, with a persistently poor function of the salivary glands, an unchanged serology (antinuclear antibody titre 1/2560), and an unchanged histopathology (Chisholm-Mason grading = 4) despite having mild fibrosis of the salivary glands.

Table 2 Report of the European group ${ }^{4}$ on the three major rheumatological autoimmune diseases treated with autologous stem cell transplantation

\begin{tabular}{llll}
\hline Autoimmune disease & Number & Died (No (\%)) & $\begin{array}{l}\text { Transplant related death } \\
(\text { No }(\%))\end{array}$ \\
\hline Systemic sclerosis & 33 & $13(39)$ & $9(27)$ \\
SLE & 14 & $2(14)$ & $2(14)$ \\
RA & 35 & $1(3)$ & $1(3)$ \\
Sjögren's syndrome (present series) & 2 & $1(50)$ & 0 \\
Total & 84 & $17(20)$ & $12(14)$ \\
\hline
\end{tabular}

In table 1 we give the characteristics of the other patient with primary SS (No 2), previously reported. It can be seen that the conditioning regimen, myeloablation, previous treatment, stem cell rescue, and bone marrow reconstitution were different. However, in this case, also, SS was not cured and there was no remission. An immunological reassessment showed persistence of the immunological imbalance and poor function of the salivary apparatus.

Table 2 shows the results for patients with three more common autoimmune rheumatic diseases (rheumatoid arthritis (RA), systemic lupus erythematosus (SLE), and scleroderma (SSc)) treated with HSCT and who received an adequate follow up. ${ }^{4}$ A total of 270 such patients are registered so far in the European Bone Marrow Transplant/EULAR database, but the number who have received adequate follow up is much smaller.

Current data suggest that best results have been obtained in RA, the worst in SSc, suggesting that $\mathrm{T}$ helper 2 oriented diseases have a poorer response.

Results for SS seem to confirm this because HSCT cured lymphoma but did not improve the autoimmune disease. No changes were recorded in the function of salivary glands, or in the synthesis of ANA, or the histopathology. The other case reported did show some early improvement in the function of the glands, but no improvement afterwards and an infection leading to death. Early recurrence of autoimmune features and of autoantibodies was seen in patients with SLE and CREST. ${ }^{5}$ We do not know whether various conditioning regimens or myeloablation approaches (with or without $T$ cell depletion) might result in different outcomes. It seems unlikely that $\mathrm{T}$ cell depletion would offer a better prospect, especially in view of the increased risk of long term immunosuppression, lymphoproliferative diseases, and infections. On the other hand, allogeneic bone marrow transplantation, even though clearly appealing given the chance of eradicating the intrinsic stem cell defect, ${ }^{6}$ does not represent a definite cure either and the related morbidity-mortality still remains too high to be accepted as a possible alternative. As benefits have been seen in around two thirds of the cases treated so far, controlled trials in the three major rheumatic diseases are eagerly waited.

We gratefully acknowledge the invaluable help we received from Professor A Tyndall, who provided us with the latest data available of the EBMT/EULAR registry on haematopoietic stem cell transplantation in autoimmune diseases.

\author{
G FERRACCIOLI \\ R DAMATO \\ $S$ DE VITA \\ Division of Rheumatology, \\ Udine Medical School, \\ University of Udine, \\ 33100 Udine, Italy \\ R FANIN \\ D DAMIANI \\ M BACCARANI \\ Division of Haematology, \\ Udine Medical School
}

gf.ferraccioli@med.uniud.it

gianfranco.ferraccioli@dpmsc.uniud.it

1 Marmont AM. New horizons in the treatment of autoimmune diseases: immunoablation and stem cell transplantation. Annual Reviews in Medicine 2000;51:115-34

2 Rosler W, Manger B, Repp R, Kalden J, Gramatski M. Autologous PBPCT in a patient with lymphoma and Sjögren's syndrome: complete remission of lymphoma without control of the autoimmune disease. Bone Marrow Transplant 1998;22:211-13.

3 Minowa R, Miyagawa S, Fukumoto T, Majima T, Shimoyama T, Fujimura Y, et al. Primary Sjögren's syndrome followed by chronic myelogenous leukemia: a case report with a ten year ogenous leukemia: a case report with
history. I Dermatol 1998;25:460-4.

4 Tyndall A, Gratwohl A. Immune ablation and stem-cell therapy in autoimmune diseases. Clinical experience. Arthritis Research (in

5 Euler HH, Marmont AM, Bacigalupo A, Fastenrath S, Dreger P, Hoffnecht $M$, et al.

Table 1 Lymphoma characteristics, conditioning regimens, side effects and outcome of the two female patients so far studied, after haematopoietic stem cell transplantation

\begin{tabular}{|c|c|c|}
\hline Variables & Patient 1 & Patient 2 \\
\hline Age (years) & 57 & 34 \\
\hline Diagnosis & $\mathrm{NHL}^{\star}$ of the lung (large cells $\mathrm{MALT}^{\star}$ lymphoma) & Immunoblastic B lymphoma \\
\hline First line treatment & 6 cycles of F-MACHOP ${ }^{\star}$ & VACOP-B ${ }^{\star}$ followed by VIPE* ${ }^{\star}$ \\
\hline \multirow[t]{4}{*}{ Conditioning regimens } & $\mathrm{ARA}^{-\mathrm{C}^{\star}} 200 \mathrm{mg} \times 2 /$ day $\times 4$ & $\mathrm{BCNU} 300 \mathrm{mg} / \mathrm{m}^{2}$ \\
\hline & $\mathrm{VP} 16^{\star} 200 \mathrm{mg} \times 2 /$ day $\times 4$ & Etoposide $800 \mathrm{mg} / \mathrm{m}^{2}$ \\
\hline & $\mathrm{CTX}^{\star} 1500 \mathrm{mg} /$ day $\times 4$ & Cytarabine $1600 \mathrm{mg} / \mathrm{m}^{2}$ \\
\hline & $\mathrm{BCNU}^{\star} 200 \mathrm{mg}$ & Melphalan $140 \mathrm{mg} / \mathrm{m}^{2}$ \\
\hline \multirow[t]{5}{*}{ Reinfusion } & $\mathrm{MNC}^{\star} 4.5 \times 10^{8} / \mathrm{kg}$ & MNC $2.42 \times 10^{8} / \mathrm{kg}$ \\
\hline & $\mathrm{CD} 340.9 \times 10^{6} / \mathrm{kg}$ & $\mathrm{CD} 344.60 \times 10^{6} / \mathrm{kg}$ \\
\hline & CD3 not counted & CD3 $37.03 \times 10^{6} / \mathrm{kg}$ \\
\hline & Days to $\mathrm{PMN}^{\star}>1 \times 10^{9} / 1=10$ days & Days to $P M N>10 \times 10^{9} / 1=11$ days \\
\hline & Days to $\mathrm{Plt}^{\star}>20 \times 10^{3} / 1=8$ days & Days to Plt $>50 \times 10^{3} / 1=18$ days \\
\hline \multirow[t]{2}{*}{ Sides effects/outcomes } & Alive in complete continous lymphoma remission after 3 years & No remission of autoimmune disease \\
\hline & No remission of autoimmune disease & Died 20 months after transplantation for Pneumocystis carinii pneumonia \\
\hline
\end{tabular}

${ }^{\star} \mathrm{NHL}=$ non-Hodgkin's lymphoma; MALT $=$ mucosa associated lymphoid tissue $; \mathrm{F}-\mathrm{MACHOP}: \mathrm{F}=5$-fluorouracil, $\mathrm{M}=$ methotrexate, $\mathrm{A}=\mathrm{Adriamycin}, \mathrm{C}=$ cyclophosphamide, $\mathrm{H}=$ doxorubicin, $\mathrm{O}=$ Oncovin, $\mathrm{P}=$ prednisone; $\mathrm{ARA}-\mathrm{C}=$ arabinoside-C; $\mathrm{VP} 16=$ etoposide $\mathrm{CTX}=$ cyclophosphamide; $\mathrm{BCNU}=$ carmustine; $\mathrm{MNC}$ = mononuclear cells; $\mathrm{PMN}=$ polymorphonuclear cells; $\mathrm{Plt}=$ platelets; VACOP-B: $\mathrm{V}=$ Vepesid, $\mathrm{A}=$ Adriamycin, $\mathrm{C}=\mathrm{cyclophosphamide}, \mathrm{O}=$ vincristine, $\mathrm{P}=$ prednisone, $\mathrm{B}=$ bleomycin; VIPE: $\mathrm{V}=$ vinblastine, $\mathrm{I}=$ ifosfamide, $\mathrm{P}=$ prednisone, $\mathrm{E}=$ etoposide. 
Early recurrence or persistence of autoimmune iseases after unmanipulated autologous stem cell transplantation. Blood 1996;88:3621-5.

6 Ikehara S. Bone marrow transplantation for autoimmune diseases. Acta Haematol 1998;99: $116-32$.

\section{Castleman's disease}

A 65 year old woman presented in February 1998 with joint pains, mild weight loss, and a low grade irregular fever. Initially, pain was localised around both shoulder joints. Subsequently, elbows, wrists, hips, and knees were affected, with morning stiffness, but withou particular swelling. The symptoms were accentuated by movement, but also persisted during the night, often keeping the patient awake. On clinical examination, there was limited painful movement of the shoulders and hips, with a marked reduction in strength. The small joints of the hands and feet were not affected. No other pathological conditions were found. Laboratory findings showed a marked increase in erythrocyte sedimentation rate (ESR; $>100 \mathrm{~mm} / 1 \mathrm{st} \mathrm{h}$ ), hyper- $\alpha_{2}$ globulinaemia and a mild anaemia, whereas enzymatic activity (serum aspartate aminotransferase, serum alanine aminotransferase, alkaline phosphatase, lactate dehydrogenase, and creatine kinase) was within the normal range. A diagnosis of polymyalgia rheumatica was made and a rapid and marked clinical improvement was obtained with low dose steroid treatment (prednisone $12.5 \mathrm{mg} /$ day). Pain disappeared, muscle strength and joint function became normal within a week. A decrease in ESR (to 40 $\mathrm{mm} / 1 \mathrm{st} \mathrm{h}$ ) and $\alpha_{2}$ globulinaemia was noted after one month. The clinical condition remained satisfactory during 1998, with a complete normalisation of ESR and $\alpha_{2}$ globulinaemia after three months.

In January 1999 she developed jaundice with pruritus and a subcontinuous fever $\left(38.5-39^{\circ} \mathrm{C}\right)$. Axial tomography and nuclear magnetic resonance disclosed compression of the biliary duct by a compact, well defined retropancreatic mass (about $4 \mathrm{~cm}$ in diameter). The laboratory pattern was typical of cholestasis (hyperbilirubinaemia, increased serum alkaline phosphatase activity). Endoscopic retrograde colangiopancreatography showed slight enlargement of the biliary tract, dilatation of the gall bladder walls, and absence of gall stones. Transit of contrast medium along the biliary tract slowed down.

Explorative laparotomy confirmed the presence of a mass compressing the common bile duct. This was removed and histological examination disclosed a lymph nodal architecture characterised by evident follicular hyperplasia. Some of the germinal centres were enlarged and comprised polymorphous follicular centre cells, whereas other germinal

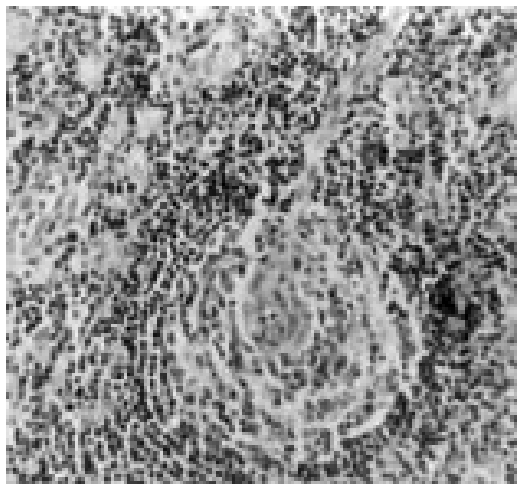

Figure 1 The post-capillary vessels penetrate the expanded follicles perpendicularly ("lollipop image"). ( $\times$ 400.)

centres were depleted of lymphocytes, and consisted predominantly of dendritic reticular cells showing vascular proliferation. The mantle zone was expanded and concentrically arranged around the atrophic germinal centres (onion skin layers). The interfollicular areas were also prominent, containing small lymphocytes, occasional eosinophils, plasma cells, and some immunoblasts, and showing numerous hyperplastic vessels of the postcapillary venous type. Occasionally these vessels, which were often hyalinised, penetrated the expanded follicles perpendicularly, giving rise to the so-called "lollipop" appearance (fig 1). An immunocytochemical study confirmed the normal organisation of the nodal structures, with a clear positivity of follicular elements for typical B cell markers CD20 and CD79a, and positivity of interfollicular lymphoid elements for $\mathrm{T}$ cell markers CD3 and CD45R0, whereas the dendritic reticular cells showed a typical positivity for CD21.

These features are distinctive of Castleman's disease, also known by the descriptive term angiofollicular lymph node hyperplasia. This is a clinical entity characterised by angiofollicular hyperplasia of the lymph nodes without the presence of any atypical cells or other signs of malignancy. Many (multicentric or systemic form) or single (monocentric or solitary form) lymph nodal groups can be affected in the process ${ }^{1}$ and two histological subsets have been recognised: a hyaline-vascular type, characterised by marked expansion of the mantle follicular zone and a plasma cell type, with diffuse plasma cell proliferation in the interfollicular tissue. ${ }^{2}$ The cause of the disease is unknown, but overproduction of interleukin $6^{3}$ has been shown in the course of Castleman's disease and a possible pathogenic role for this cytokine has been suggested. It is commonly associated with several autoimmune conditions such as systemic lupus erythematosus,
Behçet's disease, amyloidosis, and with various neoplastic diseases, ${ }^{4-7}$ but its onset during the course of polymyalgia rheumatica has not been recently reported. No data exist about the possible relation between Castleman's disease and polymyalgia, but a role for interleukin 6 can be suggested, ${ }^{8-10}$ perhaps through a stimulating action of this cytokine on monocytes and lymphocytes. The present case can be considered typical of the solitary form, hyaline-vascular type of Castleman's disease. Our patient did not present any other lymphatic disease during the subsequent months, which would seem to confirm the good prognosis of this disease.

A RICCIO

D NATALE

Dipartimento di Medicina Clinica e Sperimentale

G PETTINATO L SPARANO

Dipartimento di Scienze Biomorfologiche e Funzionali,

Sezione di Anatomia ed Istologia Patologica

A PETITO

A PUZZIELLO

Dipartimento di Chirurgia Generale Geriatria Oncologica e Tecnologie Avanzate Federico II University Medical School,

Napoli, Italy

Correspondence to: $\mathrm{Dr}$ A Riccio, via Aniello Falcone, 388 - 80127, Napoli, Italy

1 Isaacson PG. Commentary: Castleman's disease. Histopathology 1989;14:429-32.

2 Keller AR, Hochholzer L, Castleman B. Hyaline-vascular and plasma-cell types of giant lymph node hyperplasia of mediastinum and other locations. Cancer 1972;29:670-83.

3 Hsu SM, Waldron JA, Xie SS, Barlogie B. Expression of interleukin 6 in Castleman's disease. Hum Pathol 1993;24:833-9.

4 Frizzera G. Castleman's disease and related disorders. Semin Diagn Pathol 1988;5:346-64.

5 Ordi J, Grau JM, Junque A, Nomdedeu B, Palacin A, Cardesa A. Secondary (AA) amyloidosis associated with Castleman's disease. Report of two cases and review of the literature. Am J Clin Pathol 1993;100:394-7.

6 Vasef M, Katzin WE, Mendelsohn G, Reydman Vasef M, Katzin WE, Mendelsohn G, Reydman M. Report of a case of localized Castleman's disease with progression to malignant

7 Gould SJ, Diss T, Isaacson PG. Multicentric

Gould SJ, Diss T, Isaacson PG. Multicentric Castleman's disease in association with a solitary plasmacytoma. A case report. Histopathology 1990;17:135-40.

8 Dasgupta B, Panayi GS. Interleukin-6 in serum of patients with polymyalgia rheumatica and giant cell arteritis. Br J Rheumatol 1990;29: 456

9 Higashi K, Matsuki Y, Hidaka T, Aida S, Suzuki K, Nakamura H. Primary Sjögren's syndrome associated with hyaline-vascular type of Castleman's disease and autoimmune idiopathic thrombocytopenia. Scand J Rheumatol 1997; $26: 482-4$

10 Lee M, Hirokawa M, Matuoka S, Hasegawa H, Nanjo H, Matsushima T, et al. Multicentric Castleman's disease with an increase serum level of macrophage colony stimulating factor. Am J Hematol 1997;54:321-3. 